\title{
KINERJA KARYAWAN DITINJAU DARI STRES KERJA, WORK ENGAGEMENT, PENEMPATAN DAN KEPEMIMPINAN (Studi Pada FKIP UNS)
}

\author{
Esi Asmaryani, Bambang Mursito, Istiatin \\ Fakultas Ekonomi Universitas Islam Batik Surakarta \\ Email : easmaryani@gmail.com
}

\begin{abstract}
The study aims to obtain empirical evidence the effect of work stress, work engagement, placement and leadership on employee performance at FKIP UNS. The type of research is survey research. The sample of this study used a purposive sampling sample. The data collection techniques was done using questionnaire. Data analysis was performed using multiple regression analysis. This study concludes that work stress, work engagement, placement and leadership affect the performance of FKIP UNS employees simultaneously and in part the work engagement does not affect employee performance.
\end{abstract}

Keywords : Work Stress, work engagement, placement, leadership and employee performance

\section{PENDAHULUAN}

Kesuksesan suatu perusahaan ditentukan oleh sumber daya manusia, manajemen kepegawaian dan sumberdaya manusia sangat penting bagi organisasi dalam mengolah, mengatur dan memanfaatkan pegawai sehingga dapat berfungsi secara produktif untuk tercapainya tujuan organisasi. Permasalahan yang timbul dalam manajemen sumber daya manusia, merupakan masalah kinerja pegawai, karena kinerja pegawai sangat mempengaruhi keberhasilan suatu organisasi.

Kinerja diartikan sebagai proses bekerja seseorang yang hasilnya bisa dipergunakan sebagai dasar untuk menentukan apakah pekerjaan tersebut hasilnya baik atau tidak. Di lingkungan pemerintahan penilaian kinerja pegawai diukur dengan sistem prestasi dan sistem karier. Untuk penilaian pegawai berdasarkan rencana kinerja pada tingkat individu dan organisasi, dengan cara melihat target, capaian, hasil dan manfaat yang dihasilkan, beserta perilaku ASN. Penilaian kinerja karyawan di FKIP UNS berdasarkan SKP (Standar Kerja Pegawai) penilaian prestasi kerja karyawan kependidikan didominasi kategori baik. Hal ini bertentangan dengan kinerja riil karyawan di lapangan, karena masih banyak keluhan dari perijinan atau permohonan seringkali dilempar dari bagian satu ke bagian lainnya. Keterlambatan pembukaan layanan loket dan masih ditemukan karyawan pada jam kerja berkumpul-kumpul dan mengobrol.

Padahal penilaian prestasi kerja menjadi salah satu unsur dalam penilaian kinerja, dimana penilaian kinerja pegawai sangat penting sebagai dasar proses pengelolaan sumber daya manusia yang lebih baik. Penilaian kinerja dipergunakan sebagai penyesuaian kompensasi, keputusan penempatan, kebutuhan latihan dan pengembangan, perencanaan dan pengembangan karier, penyimpangan-penyimpangan proses staffing. Selain itu juga bisa digunakan untuk mengetahui kesalahan desain pekerjaan, kesempatan kerja yang adil dan tantangan eksternal.

Faktor individu, faktor organisasi dan faktor pimpinan menjadi faktor internal yang bisa mempengaruhi kinerja karyawan. Masalah umum yang sering dialami karyawan dari faktor individu yaitu stres kerja. Stres kerja dan dampaknya pada berbagai aspek dari output organisasi 
banyak dilakukan penelitian. Kontributor stres kerja dikarenakan sedikitnya sumberdaya dan peralatan yang ada, jam kerja yang berlebihan dan keadaan organisasi (Prasad et al, 2016). Stres yang dialami karyawan akan mempengaruhi kinerja menurun, beban kerja yang overload seharusnya diminimkan, sehingga stres kerja tidak terjadi yang akhirnya berdampak kinerja yang dihasilkan (Tallo, 2014).

Karyawan yang bisa mengelola stres kerja dengan baik, pada dasarnya memiliki work engagement dimana mereka dalam bekerja akan merasa energik dan efektif, karena mereka memandang pekerjaan sebagai suatu tantangan dibandingkan dengan merasakan stres dan tuntutan (Schaufeli, 2012). Menurut Setiawan \& Widjaja, (2018) mengatakan engagement penting kaitannya dengan kinerja pegawai, apabila keterikatan pegawai semakin tinggi, maka kinerja pegawai makin baik

Kinerja karyawan dipengaruhi oleh faktor penempatan dan keterlibatan dalam organisasi (Hijrah, 2014). Dalam hal mutasi atau alih tugas karyawan berlaku untuk karyawan lama dan baru. Pengalaman kerja merupakan kunci pembuka dalam menempatkan karyawan sesuai dengan jabatan yang ada, dengan pengalaman yang ada karyawan bisa bekerja secara maksimal sehingga tercipta kinerja yang semakin baik (Fadillah et al, 2013).

Penempatan pegawai sesuai dengan posisi yang benar tidak hanya menjadi keinginan perusahaan tetapi juga menjadi keinginan pegawai. Sehingga pegawai lebih termotivasi dalam bekerja dan secara tidak langsung berkontribusi bagi organisasi yang pada akhirnya mempengaruhi kinerjanya (Lomban et al, 2017). Kepemimpinan mempengaruhi keberhasilan lembaga pemerintahan, kesuksesan maupun ketidakberhasilan pelaksanaan tugas dan penyelenggaraan pemerintah. Penyelenggaraan tata pemerintahan yang baik akan terwujud dengan kepemimpinan dan dukungan institusi yang memadai, dan apabila kepemimpinan lemah maka menjadikan keruntuhan kinerja birokrasi (Istianto, 2011:2).

Kepemimpinan dan disiplin berpengaruh dan signifikan terhadap kinerja pegawai, yang berarti jika kepemimpinan dan disiplin kerja diterapkan bisa meningkatkan kinerja pegawai (Fathia et al, 2018).

Berdasarkan penjelasan di atas, penelitian ini bertujuan mengetahuai dan menganalisis pengaruh stres kerja, work engagament, penempatan dan kepemimpinan terhadap kinerja karyawan di FKIP UNS.

\section{TINJAUAN TEORI}

\section{Deskripsi Kinerja Karyawan}

Busro (2018: 89) mendefinisikan kinerja adalah hasil kerja yang dapat dicapai pekerja baik individu maupun kelompok dalam suatu organisasi, sesuai wewenang dan tanggung jawab dalam upaya mencapai visi,misi,dan tujuan organisasi.

Kinerja pegawai dapat diartikan sebagaisuatu pencapaian kerja yang diperoleh pegawai dalam organisasi yang dikerjakan dalam periode tertentu dengan rasa tanggung jawab secara moral untuk mencapai tujuan organisasi

\section{Deskripsi Stres Kerja}

Stres didefinisikan sebagai kondisi seseorang yang mengalami ketegangan sehingga mempengaruhi emosi, proses berpikir. Apabila pegawai terindikasi stres tinggi, maka berakibat berkurangnya kesanggupan seseorang tersebut dalam menghadapi lingkungan dan pekejaannya (Handoko, 2014: 193). 
Stres kerja juga diartikan suatu kondisi ketegangan dialami seseorang akibat tekanan psikologis dan atau fisik karena disebabkan tidak dapat menyeimbangi antara tuntutan perusahaan dengan kemampuannya.

\section{Deskripsi Work Engagement}

Definisi menurut Bakker et al, (2013) work engagement merupakan suatu hal positif, terpenuhi, pengalaman dengan pekerjaan yang dihubungkan dengan vigor, dedication, dan absorption dimana pegawai fokus pada satu pekerjaan sehingga waktu berjalan berlalu cepat dan terasa sukar untuk melepaskan diri dari pekerjaan tersebut.

Work engagement dapat diartikan sebagai sikap baik yang dimiliki seseorang bercirikan vigor, dedication dan absorption dengan berkomitmen tinggi untuk menyelesaikan pekerjaannya secara intelektual.

\section{Deskripsi Penempatan}

Penempatan pegawai di posisi yang sesuai dapat membantu organisasi untuk mencapai tujuan yang diinginkan. The Right Man On The Right Place merupakan istilah yang dapat diartikan bahwa menempatkan seorang pekerja harus sesuai dengan kemampuan dan keahliannya (Hasibuan, 2016:14).

Penempatan karyawan dapat diartikan sebagai suatu proses menempatkan dan mencocokan untuk penempatan pada posisi tertentu, dengan membandingkan kompetensi yang dimiliki sesuai jabatan atau pekerjaan yang diajukan oleh perusahaan.

\section{Deskripsi Kepemimpinan}

Keberhasilan suatu perusahaan tidak luput dari peran penting dari seorang atasan. Kepemimpinan merupakan suatu proses seseorang atasan baik secara langsung memberikan bimbingan dan mempengaruhi perilaku dan pekerjaan untuk mencapai tujuan (Iqbal et al, 2015).

Kepemimpinan diartikan sebagai suatu pola perilaku sesorang dalam berinteraksi untuk memotivasi dan mempengaruhi sekelompok orang yang dirancang supaya mau bekerja sama seperti apa yang diharapkan untuk mencapai tujuan perusahaan.

Kerangka pemikiran yang digunakan pada penelitian ini, dapat divisualisasikan berikut ini.

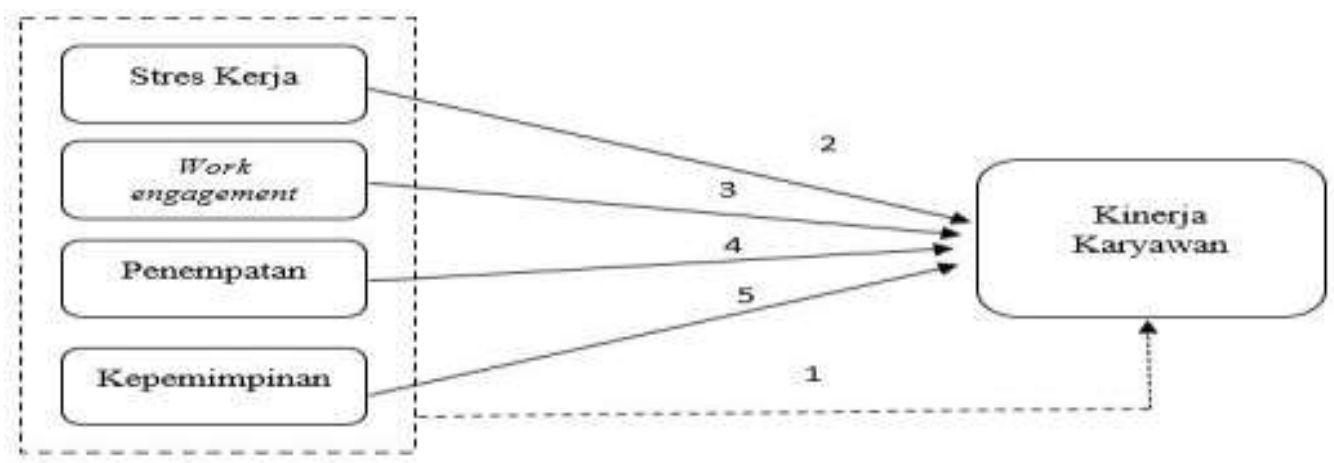

Gambar 1. Kerangka pemikiran

Sumber :

1) Astuti et al, (2016), Mansur (2017), Septiana et al, (2018), Susilo (2018).

2) Jalagat (2017), Wartono (2017), Massie et al, (2018) Darmayanti (2018), Widarta (2019).

3) Yongxin et al (2017), Insan (2017), Sulin (2019), Qodariah (2019), Ropa et al, (2020)

4) Muaja et al, (2017), Lomban et al, (2017), Sedarmayanti et al, (2018), Khaerudin et al, (2018), Sudiarditha et al, (2019). 
5) Inary et al, (2016), Widiastuti, (2017), Isvandari \& Al Indris, (2018), Ibrahim \& Daniel (2019), Maniku et al, (2019).

Berdasarkan tinjauan teori di atas, maka penelitian ini dapat dihipotesiskan sebagai berikut:

Menurut Rahardjo \& Dewi (2016) kinerja karyawan adalah hasil pekerjaan atau kegiatan seorang karyawan baik kualitas dan kuantitas sesuai tanggung jawabnya yang dilakukan pada periode waktu tertentu untuk meningkatkan nilai perusahaanya.

Hasil penelitian terdahulu yang dilakukan mengenai faktor-faktor yang mempengaruhi kinerja oleh Septiana et al, (2018) menyebutkan bahwa stres kerja dan kepemimpinan berpengaruh terhadap kinerja karyawan. Astuti et al, (2016) menunjukkan bahwa work engagement pada Bendahara Pengeluaran dengan kepemimpinan transformasi sebagai pemoderasi dapat mempengaruhi kinerja karyawan.

Susilo, (2018) hasil penelitiannya menunjukkan bahwa penempatan kerja, kepemimpinan, dan motivasi secara simultan dapat meningkatkan kinerja karyawan. Penelitian Mansur (2017) menunjukkan hasil faktor penempatan kerja dan stres kerja berpengaruh signifikan terhadap kinerja pagawai.

Oleh karena itu berdasarkan uraian di atas maka dapat ditarik sebuah hipotesis yaitu:

$H_{1}$ : Stres kerja, work engagement, penempatan dan kepemipinan secara bersama-sama berpengaruh terhadap kinerja karyawan FKIP Universitas Sebelas Maret Surakarta.

Faktor internal yang dapat mempengaruhi kinerja karyawan yatu stres kerja. Stres kerja dipengaruhi oleh kondisi mental dan fisik karyawan yang berimplikasi pada penurunan kinerja yang dikarenakan stres yang mengganggu proses pekerjaan mereka (Aulia, 2017). Berbagai tekanan kerja yang dihadapi oleh karyawan dapat menyebabkan stres kerja, akan tetapi hal tersebut merupakan hal yang baik karena dengan adanya tekanan atau stres ringan dapat membuat karyawan lebih giat dalam pekerjaanya dan dapat meningkatkan kinerja (Massie et al, 2018).

Hasil penelitian terdahulu mengenai stres kerja yang dilakukan oleh Widarta (2019), Darmayanti (2018) dan Wartono (2017) menunjukkan bahwa adanya pengaruh yang signifikan antara stres kerja terhadap kinerja karyawan.

Oleh karena itu berdasarkan uraian di atas maka dapat ditarik sebuah hipotesis yaitu:

$\mathrm{H}_{2}$ : Stres kerja berpengaruh terhadap kinerja karyawan FKIP Universitas Sebelas Maret Surakarta.

Work engagament merupakan salah satu faktor yang dapat mempengaruhi kinerja karyawan. Qodariah (2019) mendefinisikan work engagement sebagai seperangkat sikap kerja yang membawa karyawan merasakan emosi positif terhadap pekerjaannya untuk menjadi pribadi yang bermakna, mempertimbangkan beban kerja mereka untuk dikelola, dan memiliki harapan tentang masa depan pekerjaan mereka.

Work engagement adalah proses jangka panjang dan berkelanjutan, berjalan beriringan dengan kinerja karyawan (Karatepe, 2013). Semakin meningkat work engagament yang dimiliki bendahara pengeluaran, maka kinerjanya akan meningkat (Astuti et al, 2016).

Hasil penelitian terdahulu oleh Yongxin et al, (2017), Sulin (2019) dan Qodariah (2019) menunjukkan bahwa work engagement berpengaruh terhadap kinerja karyawan. Hasil berbeda diperoleh Insan (2017) dan Ropa et al, (2020) menunjukkan bawha work engagement tidak berpengaruh terhadap kinerja karyawan. Oleh karena itu berdasarkan uraian di atas maka dapat ditarik sebuah hipotesis yaitu : 


\section{$H_{3}$ : Work engagement berpengaruh terhadap kinerja karyawan FKIP Universitas Sebelas Maret Surakarta.}

Berikutnya faktor penempatan dapat mempengaruhi kinerja karyawan. Lomban, Taroreh, \& Pandowo, (2017), penempatan karyawan yang sesuai dengan posisi yang tepat tidak hanya menjadi keinginan organisasi tetapi juga menjadi keinginan karyawan. Sehingga karyawan lebih termotivasi dalam bekerja dan secara tidak langsung berkontribusi bagi organisasi yang pada akhirnya mempengaruhi kinerjanya.

Penempatan jabatan yang sesuai minat dan kemampuan akan mempengaruhi kinerja karyawan yang lebih maksimal dan sebaliknya, jika tidak sesuai maka kinerja karyawan menurun sehingga tujuan perusahaan tidak tercapai. Penempatan karyawan tidaklah mudah dilakukan karena mempunyai tingkat komponen yang berbeda-beda (Devi et al, 2016).

Hasil penelitian terdahulu oleh Lomban et al, (2017), Muaja \& Adolfina (2017), Khaerudin et al, (2018), menunjukkan hasil bahwa penempatan kerja berpengaruh positif dan signifikan terhadap kinerja karyawan. Penelitian Sedarmayanti et al, (2018), menyatakan hasil bahwa penempatan pegawai fungsional umum dari dimensi pengetahuan memiliki skor tertinggi terhadap kinerja karyawan, sedangkan menurut Sudiarditha et al, (2019) penempatan menunjukkan hasil positif dan signifikan terhadap kinerja karyawan terutama yang memiliki keahlian. Oleh karena itu berdasarkan uraian tersebut maka dapat ditarik sebuah hipotesis yaitu:

$H_{4}$ : Penempatan berpengaruh terhadap kinerja karyawan FKIP Universitas Sebelas Maret Surakarta.

Setiap organisasi terdiri dari struktur sederhana yaitu pemimpin sebagai atasan, dan karyawan sebagai bawahan. Seorang pemimpin memegang peran penting dalam menjalankan tugas dan peran di dalam organisasi agar terwujud tujuannya. Seorang pemimpin mempunyai gaya dan cara yang berbeda dalam memimpin. Seorang pemimpin harus mampu menjadikan karyawannya berprestasi dan memberikan hasil dan kinerja terbaik. Ibrahim \& Daniel (2019) menyatakan bahwa kepemimpinan yang mempunyai tanggung jawab dan mau bekerja sama dengan bawahannya secara langsung akan meningkatkan kinerja perusahaan.

Hasil penelitian yang terdahulu oleh Widiastuti (2017), Isvandari \& Al Idris (2018) menunjukkan hasil bahwa kepemimpinan dengan kinerja pegawai mempunyai hubungan yang sangat kuat dan mempunyai arah hubungan yang positif. Inary et al, (2016), Ibrahim \& Daniel (2019) dan Maniku et al, (2019) hasil penelitiannya juga menunjukkan bahwa kepemimpinan memiliki pengaruh signifikan terhadap kinerja karyawan. Oleh karena itu berdasarkan uraian di atas maka dapat ditarik sebuah hipotesis yaitu :

$H_{5}$ : Kepemimpinan berpengaruh terhadap kinerja karyawan FKIP Universitas Sebelas Maret Surakarta.

\section{METODE PENELITIAN}

Jenis penelitian tipe explanatoryresearch, dengan pendekatan kuantitatif. Penelitian berlokasi di FKIP Universitas Sebelas Maret Surakarta dilaksanakan pada bulan April-Mei 2020. Populasi pada penelitian, yaitu seluruh karyawan kependidikan FKIP UNS yang berjumlah 123 orang dan sampel berjumlah 67 orang, menggunakant teknik purposive sampling. Penelitian ini terdiri dari variabel terikat dan variabel bebas. Variabel terikat (Y) dalam penelitian ini adalah kinerja karyawan, dan variabel bebas (X) meliputi stres kerja, work engagement, penempatan dan kepemimpinan. 
Data primer dipergunakan di penelitian ini karena didapat langsung dari responden. Kuesioner adalah teknik pengumpulan data, yang diperlukan untuk mendapatkan informasi mengenai stres kerja, work engagement, penempatan, kepemimpinan dan kinerja karyawan melalui daftar pernyataan.

Metoda Analisis data yang digunakan dengan menguji instrumen penelitian yang meliputi uji validitas dan uji realibilitas. Sedangkan teknik analisis data dengan uji asumsi klasik dan analisis regresi linier berganda.

\section{HASIL DAN PEMBAHASAN}

\section{Uji Normalitas}

Pengujian normalitas dengan menggunakan Kolmogorov-Smirnov Test dengan hasil 0,200. Hasil tersebut bisa ditarik kesimpulan bahwa uji tes normalitas di penelitian ini terdistribusi normal.

\section{Uji Heterokedastisitas}

Gambar 1. Hasil Uji Heterokedastisitas

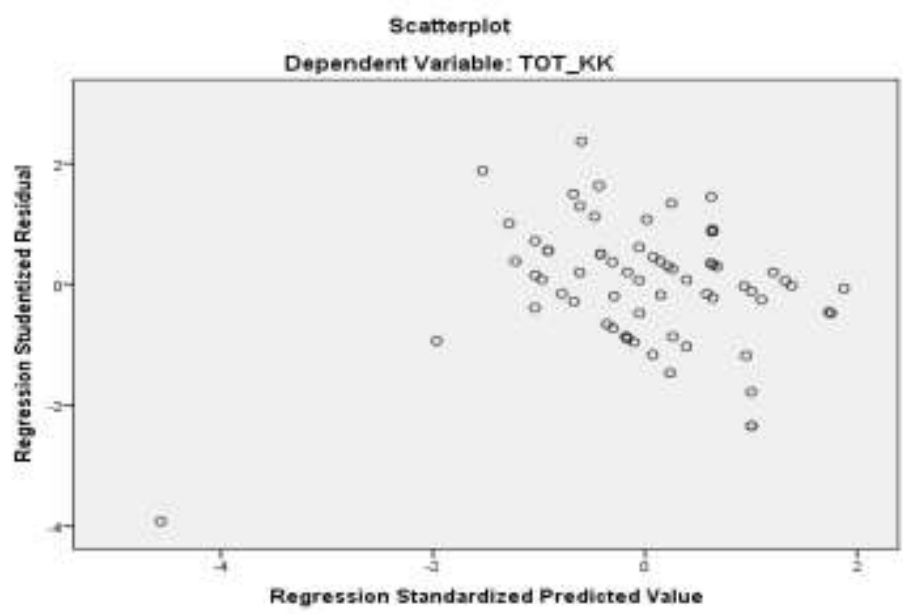

Sumber : Analisis data primer

Gambar di atas menunjukkan hasil tidak terjadi heterokedastisitas, dimana pada gambar tersebut terlihat titik-titik data tersebar disekitar angka 0 pada sumbu Y.

\section{Uji Multikolinieritas}

Uji yang digunakan untuk menghitung multikolinearitas dengan melihat nilai VIF dengan taraf signifikansi $5 \%$. 
Tabel 1. Hasil Uji Multikolinearitas

\begin{tabular}{|c|c|c|c|c|c|}
\hline Variabel & Tolerance & Syarat & VIF & Syarat & Keputusan \\
\hline Stres Kerja & 0,623 & $>0,1$ & 1,605 & $<10$ & $\begin{array}{c}\text { Tidak mengandung } \\
\text { mulikolinieritas }\end{array}$ \\
\hline $\begin{array}{l}\text { Work } \\
\text { Engagement }\end{array}$ & 0,583 & $>0,1$ & 1,717 & $<10$ & $\begin{array}{l}\text { Tidak mengandung } \\
\text { multikolinearitas }\end{array}$ \\
\hline Penempatan & 0,466 & $>0,1$ & 2,146 & $<10$ & $\begin{array}{l}\text { Tidak mengandung } \\
\text { multikolinearitas }\end{array}$ \\
\hline Kepemimpinan & 0,589 & $>0,1$ & 1,699 & $<10$ & $\begin{array}{l}\text { Tidak mengandung } \\
\text { multikilinearitas }\end{array}$ \\
\hline
\end{tabular}

Sumber : Analisis data primer

Untuk hasil uji multikolinearitas menyatakan bahwa nilai tolerance dalam regresi berganda, dimana masing-masing variabel bebas memiliki tolerance $>0,10$. Dan semua variabel bebas menunjukkan nilai VIF $<10$, maka bisa ditarik kesimpulan yaitu tidak mengandung multikolinearitas antar variabel bebas.

\section{Uji Autokorelasi}

Tabel 2. Hasil Uji Autokorelasi

\begin{tabular}{cccc}
\hline $\begin{array}{c}\text { Run } \\
\text { Test }\end{array}$ & Sig & Kriteria & Keterangan \\
\hline$-0,860$ & 0,390 & $>0,05$ & Tidak terjadi Autokorelasi \\
\hline
\end{tabular}

Sumber : Analisis data primer

Didapatkan hasil nilai run test sebesar $=-0,860$, tingkat signifikansi sebesar $=0,390>$ dari 0,05 , sehingga bisa ditarik kesimpulan yaitu model regresi tidak mengandung autokorelasi.

\section{Analisis Regresi Berganda}

Analisis data dilakukan menggunakan multiple regression analysis dengan rumus berikut ini.

$Y=2,360+0,410 X_{1}-0,137 X_{2}+0,402 X_{3}+0,280 X_{4}+\varepsilon$

Keterangan:

$\mathrm{Y}=$ Kinerja Karyawan

$\boldsymbol{\alpha} \quad=$ Konstanta

$\beta_{1}=$ Koefisien regresi stres kerja

$\mathrm{X}_{1}=$ Variabel stres kerja

$\mathrm{B}_{2} \quad=$ Koefisien regresi work engagement

$\mathrm{X}_{2} \quad=$ Variabel work engagement

$\mathrm{B}_{3}=$ Koefisien regresi penempatan

$\mathrm{X}_{3}=$ Variabel penempatan

$\mathrm{B}_{4}=$ Koefisien regresi kepemimpinan 


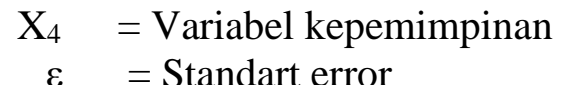

Model persamaan yang dihasilkan tersebut memperlihatkan dimana stres kerja, penempatan dan kepemimpinan mempunyai pengaruh positif, dan work engagement menunjukkan pengaruh negatif terhadap kinerja karyawan FKIP UNS.

Uji F

Tabel 3. Hasil Uji F

\begin{tabular}{ccccc}
\hline $\mathrm{F}_{\text {hitung }}$ & $\mathrm{F}_{\text {tabel }}$ & Sig & Syarat & Kesimpulan \\
\hline 22,894 & $>2,52$ & 0,000 & $<0,05$ & Model layak \\
\hline
\end{tabular}

Sumber : Analisis data primer

Hasil uji kelayakan model (uji F) secara simultan diperoleh nilai $\mathrm{F}$ hitung sebesar 22,894> dari $F_{\text {tabel }}$ sebesar 2,52 dengan nilai signifikan sebesar $0,000<0,05$ maka hipotesis pertama diterima. Sehingga bisa disimpulkan bahwa seluruh variabel bebas yang terdiri dari stres kerja, work engagament, penempatan dan kepemimpinan secara simultan dan signifikan mempengaruhi kinerja karyawan FKIP UNS. Maka model regresi yang digunakan sudah sesuai (fit).

\section{Uji t}

Hasil uji t (hipotesis) untuk variabel stres kerja,penempatan, dan kepemimpinan berpengaruh terhadap kinerja karyawan, sedangkan variabel work engagement tidak mempengaruhi kinerja karyawan.

Tabel 4. Hasil Uji Hipotesis

\begin{tabular}{cccccc}
\hline Hipotesis & F atau t hitung & Fatau t tabel & Sig & Syarat & Kesimpulan \\
\hline H1 & 22,894 & $>2,52$ & 0,000 & $<0,05$ & Diterima \\
H2 & 3,923 & $>1,999$ & 0,000 & $<0,05$ & Diterima \\
H3 & $-1,885$ & $>-1,999$ & 0,064 & $<0,05$ & Ditolak \\
H4 & 3,333 & $>1,999$ & 0,001 & $<0,05$ & Diterima \\
H5 & 2,473 & $>1,999$ & 0,016 & $<0,05$ & Diterima \\
\hline
\end{tabular}

Sumber : Analisis data primer

\section{Koefisien Determinasi $\left(\mathbf{R}^{2}\right)$}

Tabel 5. Hasil Uji $\mathrm{R}^{2}$

\begin{tabular}{cc}
\hline $\begin{array}{c}\text { Adjusted R } \\
\text { Square }\end{array}$ & Kesimpulan \\
\hline 0,570 & Berpengaruh sebesar $57 \%$ \\
\hline
\end{tabular}

Sumber : Analisis data primer 
Hasil analisis koefisien determinasi diperoleh angka 0,570, artinya sebesar 57\% variabilitas kinerja karyawan dipengaruhi oleh variabel stres kerja, work engagement, penempatan,dan kepemimpinan. Sisa sebesar $43 \%$ variasi kinerja karyawan diperoleh variabel lain diluar model ini.

\section{Pembahasan}

1) Pengaruh stres kerja, work engagement, penempatan dan kepemimpinan secara simultan terhadap kinerja karyawan

Hipotesis penelitian yang dirumuskan menyatakan bahwa stres kerja, work engagement, penempatan dan kepemimpinan berpengaruh singnifikan secara simultan terhadap kinerja karyawan. Hipotesis tersebut dapat dibuktikan kebenarannya. Hal ini ditunjukkan dengan perolehan $\mathrm{F}=22,894$ dan tingkat signifikan $0,000<0,05$.

Temuan ini relevan dengan penelitian Astuti et al,(2016), dimana work engagement dan kepemimpinan transfomasi sebagai pemoderasi dapat mempengaruhi kinerja pegawai. Sedangkan hasil temuan Mansur (2017), menunjukkan penempatan dan stres kerja berpengaruh secara bersama-sama terhadap kinerja pagawai. Temuan penelitian oleh Septiana et al, (2018) menyatakan stres kerja dan kepemimpinan secara simultan berpengaruh terhadap kinerja karyawan. Dan hasil temuan penelitian oleh Susilo (2018) menunjukkan penempatan kerja dan kepemimpinan dapat meningkatkan kinerja pegawai.

\section{2) Pengaruh stres kerja terhadap kinerja karyawan.}

Hasil penelitian menyebutkan stres kerja berpengaruh signifikan terhadap kinerja karyawan. Berdasarkan data lapangan yang diperoleh peneliti, jumlah karyawan terutama bagian administrasi tidak seimbang untuk melayani mahasiswa, dosen maupun pihak luar yang meminta pelayanan. Banyaknya beban kerja yang harus dihadapi menjadikan tekanan yang bisa menimbulkan stres kerja, yang pada akhirnya mempengaruhi kinerja karyawan.

Temuan ini relevan dengan studi yang dilakukan oleh Widarta (2019), Darmayanti (2018), Wartono (2017), dan Massie et al, (2018) dimana variabel stres kerja memiliki pengaruh yang signifikan terhadap kinerja pegawai.

\section{3) Pengaruh work engagement terhadap kinerja karyawan.}

Hasil penelitian menunjukkan bahwa work engagament tidak mempengaruhi kinerja karyawan. Hasil yang didapat peneliti di lapangan, tidak munculnya engagement dalam diri karyawan, dikarenakan insentif yang didapat tidak sesuai dengan beban kerja dan tanggung jawab yang diemban. Selain itu juga dari faktor usia dari karyawan yang sudah memasuki masa pensiun, dimana semangat kerjanya mulai menurun yang dikarenakan kemampuan fisik dan pikiran yang menjadikan menurunnya kinerja karyawan.

Temuan penelitian ini tidak relevan dengan penelitian Yongxin et al, (2017), Sulin (2019) dan Qodariah (2019) yanng menghasilkan temuan bahwa work engagement mempengaruh terhadap kinerja pegawai. Temuan penelitian ini relevan dengan penelitian oleh Insan (2017) dan Ropa et al,(2020) dimana work engagement tidak mempengaruhi kinerja karyawan.

\section{4) Pengaruh penempatan terhadap kinerja karyawan.}

Hasil penelitian menunjukkan bahwa penempatan berpengaruh terhadap kinerja karyawan. Hasil peneliti dilapangan menunjukkan bahwa untuk penempatan karyawan di FKIP telah sesuai dengan tingkat pendidikan, usia, masa kerja, dan keahlian serta kemampuan yang dimiliki oleh karyawan. 
Temuan ini memperlihatkan bahwa penempatan berpengaruh signifikan terhadap kinerja karyawan FKIP UNS relevan dengan hasil-hasil sebelumnya. Hasil dari beberapa penelitian seperti Lomban et al, (2017), Muaja \& Adolfina, (2017), Sedarmayanti et al, (2018), dan Sudiarditha et al, (2019) penempatan menunjukkan hasil signifikan terhadap kinerja karyawan.

\section{5) Pengaruh kepemimpinan terhadap kinerja karyawan.}

Hasil penelitian menunjukkan bahwa kepemimpinan berpengaruh terhadap kinerja karyawan di FKIP UNS. Hal ini dibuktikan dengan hasil peneliti yang diperoleh, menunjukkan bahwa kepemimpinan di FKIP UNS, dalam hal ini atasan. Selalu memberikan kesempatan maupun dukungan bagi tenaga kependidikan untuk mengikuti pelatihan dan pemilihan tenaga kependidikan berprestasi. Selain itu pimpinan juga mendorong karyawannya untuk menempuh jenjang pendidikan yang lebih tinggi.

Pemberian keleluasaan dan dorongan bagi karyawan untuk mengembangkan prestasi maupun pemberian kesempatan belajar demi jenjang karier mejadikan karyawan lebih semangat dalam bekerja yang pada akhirnya mempengaruhi kinerjanya.

Hasil penelitian ini sejalan dengan Inary et al, (2016), Widiatuti (2017), Isvandari \& Al Idris (2018), Ibrahim \& Daniel (2019) dan Maniku et al, (2019) menunjukkan kepemimpinan dengan kinerja karyawan mempunyai hubungan positif dan signifikan terhadap kinerja karyawan.

\section{KESIMPULAN DAN SARAN}

\section{Kesimpulan}

Berikut kesimpulan penelitian yang diperoleh berdasarkan analisis data yang sudah dipaparkan adalah:

1) Stres kerja, work engagement, penempatan dan kepemimpinan secara simultan dan signifikan berpengaruh terhadap kinerja karyawan FKP UNS. Hal ini diperolehan dengan thitung 3,333 dan tingkat signifikan $0,001<0,05$. Nilai besarnya pengaruh stres kerja, work engagement, penempatan dan kepemimpinan terhadap kinerja karyawan ditentukan oleh nilai $\mathrm{R}^{2}$ yang dihasilkan sebesar 0,570 atau $57 \%$. Nilai $\mathrm{R}^{2}=0,570$ mengindikasikan bahwa variabel bebas yang terdiri stres kerja, work engagement, penempatan dan kepemimpinan secara simultan menentukan vraiabilitas kinerja karyawan FKIP UNS sebesar 57\%.Sisanya sebesar 47\% diberikan oleh variabel lainnya di luar model ini.

2) Stres kerja berpengaruh signifikan terhadap kinerja karyawan. Hal ini dibuktikan tingkat nilai signifikansi t $(0,000)$ kurang dari 0,05 . Koefisien regresi dengan tanda positif yaitu sebesar 0,410 dimaknai bahwa stres kerja memberikan pengaruh positif terhadap kinerja karyawan.

3) Work engagement tidak berpengaruh signifikan terhadap kinerja karyawan. Hasil dari regresi untuk variabel stres kerja mempunyai nilai signifikansi t $(0,064)$ sehingga dapat disimpulkan bahwa work engagement tidak berpengaruh terhadap kinerja karyawan karena nilainya lebih dari 0,05.

4) Penempatan berpengaruh positif signifikan terhadap kinerja karyawan. Nilai signifikansi t dan koefisien regresi dalam regresi berganda menunjukkan penempatan terbukti positif signifikan berpengaruh terhadap kinerja karyawan karena nilai t kurang dari 0,05 yaitu 0,001 dan koefisien regresi dengan tanda positif yaitu sebesar 0,402.

5) Kepemimpinan berpengaruh positif signifikan terhadap kinerja karyawan. Nilai signifikansi t dan koefisien regresi dalam regresi berganda menunjukkan kepemimpinan terbukti positif 
signifikan berpengaruh terhadap kinerja karyawan karena nilai t kurang dari 0,05 yaitu 0,016 dan koefisien regresi dengan tanda positif yaitu sebesar 0,280.

\section{Saran}

Saran yang bisa diberikan peniliti untuk penelitian selanjutnya adalah sebagai berikut:

1) Penelitian selanjutnya dapat mempertimbangkan variabel lain, seperti motivasi, kompetensi, lingkungan kerja dalam menentukan hal-hal yang mempengaruhi kinerja karyawan.

2) Sampel instansi bisa ditambah jumlah dan diperluas lingkup wilayahnya sehingga hasil penelitian bisa lebih digeneralisasikan

\section{DAFTAR PUSTAKA}

Aulia (2017). Stres Kerja dan Kinerja : Meta Analisis. Humanitas, 95-106 https://doi.org/10.26555/humanitas.v13i2.6066.

Bakker, A. B., Xanthopoulou, D., \& Fiscbach, A. (2013). Work Engagement Among Employee Facing Emotional Demands. Journal of Personnel Psychology, 74-84.

Busro, D. M. (2018). Teori-Teori Manajemen Sumber Daya Manusia. Jakarta: Prenada Media.

Fadilah, A. N., \& Hakim, A. (2013). Pengaruh Penempatan Pegawai terhadap Kinerja. Jurnal Administrasi Publik, 847-852.

Fathia, M., Suharto, \& Sodikin, A. (2018). Effect of Leadership and dicipline on employee performance through employee organization commitment Bank Jabar Banten (BJB). International Journal of Multidisciplinary Research and Development, 130-139.

Handoko, T. (2014). Manajemen Personalia dan Sumber Daya Manusia. Yogyakarta: BPFE

Hasibuan, M. S. (2016). Manajemen Sumber Daya Manusia. Edisi Revisi. Jakarta: Bumi Aksara.

Hijrah, Sjahruddin, H., \& Heslina. (2014). Pengaruh Penempatan dan Keterlibatan Kerja Terhadap Kinerja Karyawan Pada PT. Bank BNI (Persero) Tbk Cabang Makassar. E-Library STIE YPBUP Bangaya, 1-15.

Iqbal, Anwar, \& Haider. (2015). Effect of Leadership Style on Employee Performance. Arabian J Bus Manag Review, 1-6.

Istianto, B. (2011). Manajemen Pemerintahan dalam Perspektif Pelayanan Publik. Jakarta: Mitra Wacana Media.

Karatepe, O. M (2013). High-performance work practice and hotel employee performance: The mediation of work engagement. International Jurnal of Hospitality Management, 132140. 
Lomban, M., Taroreh, R., \& Pandowo, M. (2017). Pengaruh Penempatan Kerja dan Gaya Kepemimpinan Terhadap Kinerja Pegawai di Kantor Dinas Kependudukan dan Catatan Sipil Manado. Jurnal EMBA, 4313-4323.

Massie, R. N., William, A. A., \& Rumawas, W. (2018). Pengaruh Stres Kerja terhadap Kinerja Karyawan Pada Kantor Pengelola It Center Manado. Jurnal Administrasi Bisnis, 41-49.

Prasad, K., Vaidya, R., Kumar, V., \& Rekha, B. (2016). A Comparative Analysis on the Causes of Occupational Stress among Men and Women Emplyees and Its Effect on Performance at the workplace of information Technology Sector, Hyderabad. International Journal of Management Excellence, 796.

Qodariah. (2019). Analisis Deskripsi Pengaruh Work Engagement Terhadap Kinerja Karyawan: Ability (A), Effort (E), Support (S) PT Surveyor Indonesia. Journal of Management and Business, 53-64.

Rahardjo, K. S., \& Dewi, I. G. (2016). Pengaruh Stres Kerja Pada Kinerja karyawan dengan Locus Oof Control sebagai Variabel Pemoderasi. Matrik: Jurnal Manajemen, Strategi Bisnis dan Kewirausahaan, 117-127.

Schaufeli, W. (2012). Work Engagement: What Do We Know and Where Do We Go? Romanian Journal of Applied Psychology, 3-10

Setiawan, O. D., \& Widjaja, D. C. (2018). Analisa pengaruh Employee Engagement Terhadap Kinerja Karyawan dengan Kepuasan Kerja sebagai Variabel Intervening di Shangri-La Hotel Surabaya. Jurnal Hospitality dan Manajemen Jasa, 120-134.

Tallo, Y. (2014). Pengaruh Stres Kerja dan Kompensasi tehadap Kinerja Karyawan pada Perhutani Plywood Industry di Kabupaten Kediri Jawa Timur. Jurnal Ilmiah Mahasiswa FEB, 1-9. 